\title{
Fulminant legionellosis in two patients treated with infliximab for Crohn's disease: Case series and literature review
}

\author{
Adam Hofmann MD ${ }^{1}$, Yanick Beaulieu MD FRCPC ${ }^{2}$, Francis Bernard MD FRCPC ${ }^{3}$, Philippe Rico MD FRCPC 3
}

\begin{abstract}
A Hofmann, Y Beaulieu, F Bernard, P Rico. Fulminant legionellosis in two patients treated with infliximab for Crohn's disease: Case series and literature review. Can J Gastroenterol 2009;23(12):829-833.

Two cases of fulminant pulmonary legionellosis, complicated by prolonged intensive care unit stays and acute respiratory distress syndrome, and who were recently treated with infliximab for Crohn's disease, are described. A review of the literature revealed three additional cases in patients with inflammatory bowel disease, and a total of 22 cases of Legionella pneumophila pneumonia in the context of treatment with antitumour necrosis (TNF)-alpha medications. The median age of the patients was 49 years, and men and women were affected equally. The case fatality rate was $14 \%$ (three of 22 ). Early recognition and treatment of this anti-TNF-alpha-related complication would likely result in reduced mortality and morbidity. Physicians prescribing anti-TNF-alpha drugs should be aware of this association.
\end{abstract}

Key Words: Crohn's disease; Infliximab; Legionella pneumophila; Tumour necrosis factor-alpha

T egionella pneumophila is a ubiquitous intracellular pathogen, Land a common etiological agent in community-acquired pneumonia (1). The association of $L$ pneumophila pneumonia with antitumour necrosis factor (TNF)-alpha has been reported previously in the literature (2-10) and twice before in patients receiving infliximab for Crohn's disease $(4,5)$. With the growing popularity of anti-TNF-alpha agents for the treatment of inflammatory bowel disease, it is important for physicians to be aware of this readily treatable and potentially life-threatening complication. Two cases of fulminant legionellosis associated with recent infliximab therapy in the context of Crohn's disease are reported, followed by a review and synthesis of the literature describing this association.

\section{CASE PRESENTATIONS}

Both cases were transferred from the referring community hospital to the intensive care unit (ICU) of the Hôpital Sacré-Cœur (Montreal, Quebec) for advanced ventilatory management. At the time of transfer, the referring hospital was undergoing major renovations to its physical plant, including its water supply system. To date, three patients with nosocomial L pneumophila pneumonia have been found and local public health authorities have conducted an outbreak investigation.

\section{Légionellose fulminante chez deux patients traités par infliximab pour maladie de Crohn : Série de cas et revue de la littérature}

\begin{abstract}
On décrit ici deux cas de légionellose pulmonaire fulminante compliqués de séjours prolongés aux soins intensifs et d'un syndrome de détresse respiratoire aiguë qui avaient récemment été traités par infliximab pour une maladie de Crohn. Une revue de la littérature a révélé trois autres cas chez des patients atteints de maladie inflammatoire de l'intestin et, en tout, 22 cas de pneumonie à Legionella pneumophila dans le contexte d'un traitement par anti-TNF-alpha. Lâge médian des patients était de 49 ans et les hommes et les femmes étaient affectés dans une même proportion. Le taux de mortalité a été de $14 \%$ (trois sur 22). La reconnaissance et le traitement précoces de cette complication liée aux anti-TNF-alpha permettraient de réduire la mortalité et la morbidité. Les médecins qui prescrivent des antiTNF-alpha doivent être au courant de ce lien.
\end{abstract}

${ }^{1}$ Department of General Internal Medicine, McGill University Faculty of Medicine; ${ }^{2}$ Department of Cardiology and Critical Care; ${ }^{3}$ Department of Internal Medicine and Critical Care, Hôpital Sacré-Cour, Montreal University, Montreal, Quebec

Correspondence: Dr Adam Hofmann, Department of Internal Medicine, Sir Mortimer B Davis Jewish General Hospital, Suite G-050, 3755 Côte-Sainte-Catherine Road, Montreal, Quebec H3T 1E2. Telephone 514-340-8222 ext 4974, fax 514-340-7905, e-mail adam.hofmann@mail.mcgill.ca

Received for publication March 13, 2009. Accepted March 22, 2009 
TABLE 1

Clinical characteristics of tumour necrosis factor (TNF)-alpha antagonist-associated legionellosis patients

\begin{tabular}{|c|c|c|c|c|c|c|c|c|c|c|c|c|}
\hline $\begin{array}{l}\text { Author } \\
\text { (reference) }\end{array}$ & $\begin{array}{l}\text { Age, } \\
\text { years }\end{array}$ & Sex & $\begin{array}{l}\text { Anti-TNF- } \\
\text { alpha drug }\end{array}$ & $\begin{array}{c}\text { Treatment } \\
\text { duration }\end{array}$ & Indication & $\begin{array}{l}\text { Concomitant } \\
\text { immuno- } \\
\text { suppressive } \\
\text { therapy }\end{array}$ & $\begin{array}{l}\text { Comor- } \\
\text { bidities }\end{array}$ & $\begin{array}{c}\text { Clinical and } \\
\text { radiological } \\
\text { features }\end{array}$ & $\begin{array}{l}\text { Community- } \\
\text { acquired (C) } \\
\text { or } \\
\text { nosocomial } \\
\text { (N) }\end{array}$ & $\begin{array}{l}\text { Diagnostic } \\
\text { modality } \\
\text { (serogroup) }\end{array}$ & $\begin{array}{c}\text { Antibiotic } \\
\text { therapy }\end{array}$ & Outcome \\
\hline \multicolumn{13}{|c|}{ Inflammatory bowel disease-associated clinical cases } \\
\hline Case A & 26 & M & $\begin{array}{l}\text { IFMB } \\
\qquad(5 \mathrm{mg} / \mathrm{kg})\end{array}$ & 4 weeks & CD & $\begin{array}{l}\text { MP, } \\
\text { Prednisone }\end{array}$ & Smoker & $\begin{array}{l}\text { BL pneumonia, } \\
\text { ARDS requiring } \\
\text { HFOV, acute } \\
\text { kidney damage } \\
\text { requiring } \\
\text { hemodialysis }\end{array}$ & $\mathrm{N}$ & $\begin{array}{l}\text { LPAg- } \\
\text { positive } \\
\text { (LP1) }\end{array}$ & Macrolide & $\begin{array}{l}\text { Admitted to } \\
\text { ICU, severe } \\
\text { hypoxia, } \\
\text { hemodialysis- } \\
\text { dependent, } \\
\text { recovered }\end{array}$ \\
\hline Case B & 59 & M & $\begin{array}{l}\text { IFMB } \\
\text { (5 mg/kg, } \\
\text { two } \\
\text { doses) }\end{array}$ & 4 weeks & CD & $\begin{array}{l}\text { Methyl- } \\
\text { prednisolone }\end{array}$ & Smoker & $\begin{array}{l}\text { BL pneumonia with } \\
\text { abscess formation, } \\
\text { ARDS requiring } \\
\text { HFOV }\end{array}$ & $\mathrm{N}$ & $\begin{array}{l}\text { LPAg- } \\
\text { positive } \\
\text { (LP1) }\end{array}$ & Macrolide & $\begin{array}{l}\text { Admitted to } \\
\text { ICU, died as a } \\
\text { result of com- } \\
\text { plications of } \\
\text { his ICU stay, } \\
\text { and sequelae } \\
\text { of a massive } \\
\text { vertebrobasi- } \\
\text { lar stroke }\end{array}$ \\
\hline $\begin{array}{l}\text { Beigel } \\
\text { et al (2) }\end{array}$ & 58 & M & IFMB & & $C D$ & $\begin{array}{l}\text { Azathioprine, } \\
\text { mesala- } \\
\text { mine, pred- } \\
\text { nisolone }\end{array}$ & Smoker & $\begin{array}{l}\text { UL pneumonia, } \\
\text { respiratory failure } \\
\text { requiring ICU } \\
\text { admission }\end{array}$ & C & $\begin{array}{l}\text { BAL culture, } \\
\text { LPAg- } \\
\text { positive } \\
\text { (LP1) }\end{array}$ & FLQ & $\begin{array}{l}\text { Admitted to } \\
\text { ICU, } 2 \text { weeks } \\
\text { of mechanical } \\
\text { ventilation, } \\
\text { complete } \\
\text { recovery }\end{array}$ \\
\hline $\begin{array}{l}\text { Kohn } \\
\text { et al (4) }\end{array}$ & 71 & M & IFMB & 11 days & UC & $\begin{array}{l}\text { Mesalazine, } \\
\text { IV glucocor- } \\
\text { ticoids }\end{array}$ & N/A & N/A & $\mathrm{N}$ & $\begin{array}{l}\text { PCR of } \\
\text { sputum } \\
\text { sample }\end{array}$ & $\mathrm{N} / \mathrm{A}$ & $\begin{array}{l}\text { Death from } \\
\text { septic shock }\end{array}$ \\
\hline $\begin{array}{l}\text { Tubach } \\
\text { et al (5) }\end{array}$ & 27 & $\mathrm{~F}$ & $\begin{array}{l}\text { IFMB } \\
\qquad(250 \mathrm{mg})\end{array}$ & 1 week & $C D$ & $\begin{array}{l}\text { Azathioprine } \\
\text { (200 mg/ } \\
\text { day), } \\
\text { prednisone } \\
15 \mathrm{mg} / \text { day })\end{array}$ & None & $\begin{array}{l}\text { ARDS, UL } \\
\text { pneumonia }\end{array}$ & C & $\begin{array}{l}\text { LPAg- } \\
\text { positive } \\
\text { (LP1), BAL } \\
\text { culture }\end{array}$ & $\begin{array}{l}\text { Rifampicin, } \\
\text { FLQ }\end{array}$ & $\begin{array}{l}\text { Recovered, } \\
\text { experienced } \\
\text { second } \\
\text { episode with } \\
\text { reintroduction } \\
\text { of IFMB }\end{array}$ \\
\hline
\end{tabular}

Clinical cases associated with other rheumatic conditions or other inflammatory condition indications for anti-TNF-alpha therapy

\begin{tabular}{|c|c|c|c|c|c|c|c|c|c|c|c|c|}
\hline $\begin{array}{l}\text { Tubach } \\
\text { et al (5) }\end{array}$ & 43 & M & $\begin{array}{l}\text { ALMB } \\
\text { (40 mg } \\
\text { biweekly) }\end{array}$ & 71 weeks & RA & $\begin{array}{l}\text { MTX, } \\
\text { Prednisone }\end{array}$ & $\begin{array}{l}\text { Diabetes } \\
\text { mellitus }\end{array}$ & $\begin{array}{l}\text { BL pneumonia, } \\
\text { vomiting }\end{array}$ & C & $\begin{array}{l}\text { LPAg- } \\
\text { positive } \\
\text { (LP1) }\end{array}$ & FLQ & Recovered \\
\hline $\begin{array}{l}\text { Tubach } \\
\text { et al (5) }\end{array}$ & 55 & $\mathrm{~F}$ & $\begin{array}{l}\text { ALMB } \\
\qquad(40 \mathrm{mg} \\
\text { monthly) }\end{array}$ & 26 weeks & RA & $\begin{array}{l}\text { MTX }(7.5 \text { mg/ } \\
\text { week), } \\
\text { prednisone } \\
\text { (8 mg/day) }\end{array}$ & None & UL pneumonia & C & $\begin{array}{l}\text { LPAg- } \\
\text { positive } \\
\text { (LP1) }\end{array}$ & $\begin{array}{l}\text { Macrolide, } \\
\text { rifampicin }\end{array}$ & Recovered \\
\hline $\begin{array}{l}\text { Tubach } \\
\text { et al (5) }\end{array}$ & 67 & M & $\begin{array}{l}\text { ETCP } \\
\text { (25 mg } \\
\text { twice } \\
\text { weekly) }\end{array}$ & 16 weeks & RA & $\begin{array}{l}\text { MTX (12.5 } \\
\text { mg/week), } \\
\text { predniso- } \\
\text { lone } \\
\text { (10 mg/day) }\end{array}$ & $\begin{array}{l}\text { Tobacco- } \\
\text { related } \\
\text { COPD }\end{array}$ & $\begin{array}{l}\text { UL multilobar } \\
\text { pneumonia, ARDS, } \\
\text { acute kidney } \\
\text { damage requiring } \\
\text { hemodialysis }\end{array}$ & C & $\begin{array}{l}\text { LPAg posi- } \\
\text { tive (LP1) } \\
\text { and BAL } \\
\text { culture }\end{array}$ & $\begin{array}{l}\text { Rifampicin, } \\
\text { FLQ }\end{array}$ & $\begin{array}{l}\text { Admitted to } \\
\text { ICU, } \\
\text { recovered }\end{array}$ \\
\hline $\begin{array}{l}\text { Tubach } \\
\text { et al (5) }\end{array}$ & 46 & $\mathrm{~F}$ & IFMB & 73 weeks & PD & $\begin{array}{l}\text { Prednisone } \\
\text { (10 mg/day), } \\
\text { pipobroman } \\
\text { (75 mg/day) }\end{array}$ & $\begin{array}{l}\text { Primary } \\
\text { thrombo- } \\
\text { cythemia }\end{array}$ & $\begin{array}{l}\text { BL lower lobe } \\
\text { pneumonia, pleural } \\
\text { effusion, ARDS, } \\
\text { nausea }\end{array}$ & C & $\begin{array}{l}\text { LPAg- } \\
\text { positive } \\
(\text { LP1) }\end{array}$ & $\begin{array}{l}\text { Macrolide, } \\
\text { rifampicin }\end{array}$ & $\begin{array}{l}\text { Admitted to } \\
\text { ICU, alive at } \\
\text { discharge }\end{array}$ \\
\hline $\begin{array}{l}\text { Tubach } \\
\text { et al (5) }\end{array}$ & 58 & M & $\begin{array}{l}\text { IFMB } \\
\qquad(5 \mathrm{mg} / \mathrm{kg})\end{array}$ & 3 weeks & Psoriasis & None & $\begin{array}{l}\text { Smoker } \\
\text { (15 pack- } \\
\text { years) }\end{array}$ & $\begin{array}{l}\text { UL upper lobe } \\
\text { pneumonia, small } \\
\text { pleural effusion }\end{array}$ & C & $\begin{array}{l}\text { LPAg-positive } \\
\text { (LP1) and } \\
\text { PCR-positive } \\
\text { sputum } \\
\text { samples }\end{array}$ & $\begin{array}{l}\text { Macrolide, } \\
\text { FLQ }\end{array}$ & Recovered \\
\hline $\begin{array}{l}\text { Tubach } \\
\text { et al (5) }\end{array}$ & 40 & $\mathrm{M}$ & $\begin{array}{l}\text { ALMB } \\
\text { (40 mg } \\
\text { biweekly) }\end{array}$ & 34 weeks & RA & $\begin{array}{l}\text { Sulfasalazine } \\
\text { ( } 2 \text { g/day), } \\
\text { betametha- } \\
\text { sone } \\
\text { ( } 2 \text { mg/day })\end{array}$ & $\begin{array}{l}\text { Diabetes } \\
\text { mellitus, } \\
\text { tobacco- } \\
\text { related } \\
\text { COPD }\end{array}$ & $\begin{array}{l}\text { UL bilobar } \\
\text { pneumonia, } \\
\text { myalgia, vomiting }\end{array}$ & C & $\begin{array}{l}\text { LPAg- } \\
\text { positive } \\
\text { (LP1) }\end{array}$ & $\begin{array}{l}\text { Rifampicin, } \\
\text { FLQ }\end{array}$ & Recovered \\
\hline
\end{tabular}




\begin{tabular}{|c|c|c|c|c|c|c|c|c|c|c|c|c|}
\hline $\begin{array}{l}\text { Author } \\
\text { (reference) }\end{array}$ & $\begin{array}{l}\text { Age, } \\
\text { years }\end{array}$ & Sex & $\begin{array}{l}\text { Anti-TNF- } \\
\text { alpha drug }\end{array}$ & $\begin{array}{c}\text { Treatment } \\
\text { duration }\end{array}$ & Indication & $\begin{array}{c}\text { Concomitant } \\
\text { immuno- } \\
\text { suppressive } \\
\text { therapy }\end{array}$ & $\begin{array}{l}\text { Comor- } \\
\text { bidities }\end{array}$ & $\begin{array}{c}\text { Clinical and } \\
\text { radiological } \\
\text { features }\end{array}$ & $\begin{array}{l}\text { Community- } \\
\text { acquired (C) } \\
\text { or } \\
\text { nosocomial } \\
\text { (N) }\end{array}$ & $\begin{array}{l}\text { Diagnostic } \\
\text { modality } \\
\text { (serogroup) }\end{array}$ & $\begin{array}{c}\text { Antibiotic } \\
\text { therapy }\end{array}$ & Outcome \\
\hline $\begin{array}{l}\text { Tubach } \\
\text { et al (5) }\end{array}$ & 45 & $\mathrm{~F}$ & $\begin{array}{l}\text { ALMB } \\
\text { (40 mg } \\
\text { biweekly) }\end{array}$ & 36 weeks & JRA & $\begin{array}{l}\text { MTX (15mg/ } \\
\text { week), } \\
\text { prednisone } \\
\text { (5 mg/day) }\end{array}$ & Smoker & $\begin{array}{l}\text { UL pneumonia, } \\
\text { delirium }\end{array}$ & C & $\begin{array}{l}\text { LPAg-positive } \\
\text { (LP1) }\end{array}$ & $\begin{array}{l}\text { Macrolide, then } \\
\text { FLQ }\end{array}$ & Recovered \\
\hline $\begin{array}{l}\text { Tubach } \\
\text { et al (5) }\end{array}$ & 47 & M & $\begin{array}{l}\text { ALMB } \\
\text { (40 mg } \\
\text { biweekly) }\end{array}$ & 50 weeks & RA & $\begin{array}{l}\text { Prednisone } \\
\text { (5 } \mathrm{mg} / \text { day })\end{array}$ & $\begin{array}{l}\text { Smoker, } \\
\text { water- } \\
\text { cleaning } \\
\text { system } \\
\text { worker }\end{array}$ & $\begin{array}{l}\text { BL upper lobe pneu- } \\
\text { monia, ARDS, } \\
\text { pneumothorax }\end{array}$ & C & $\begin{array}{l}\text { LPAg-positive } \\
\text { (LP1), BAL } \\
\text { culture }\end{array}$ & Rifampicin, FLQ & $\begin{array}{l}\text { Admitted to } \\
\text { ICU, } \\
\text { recovered }\end{array}$ \\
\hline $\begin{array}{l}\text { Dixon } \\
\text { et al (10) }\end{array}$ & 49 & M & IFMB & 16 weeks & RA & N/A & N/A & N/A & N/A & N/A & N/A & N/A \\
\hline $\begin{array}{l}\text { Dixon } \\
\text { et al (10) }\end{array}$ & 59 & M & IFMB & $\begin{array}{l}128 \\
\text { weeks }\end{array}$ & RA & N/A & N/A & N/A & N/A & N/A & N/A & N/A \\
\hline $\begin{array}{l}\text { Eisendle } \\
\text { and } \\
\text { Fritsch (9) }\end{array}$ & 56 & M & $\begin{array}{l}\text { IFMB } \\
\text { (5 mg/kg, } \\
\text { two } \\
\text { doses })\end{array}$ & 2 weeks & EP & $\begin{array}{l}\text { Prednisolone } \\
20 \text { mg/day }\end{array}$ & $\begin{array}{l}\text { Diabetes } \\
\text { mellitus } \\
\text { and } \\
\text { steroid } \\
\text { myopathy }\end{array}$ & $\begin{array}{l}\text { UL pneumonia, } \\
\text { septic shock }\end{array}$ & 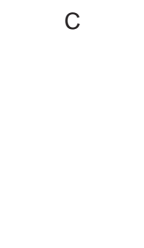 & $\begin{array}{l}\text { LPAg- } \\
\text { negative, } \\
\text { BAL and } \\
\text { postmortem } \\
\text { culture for } \\
\text { serogroup } 4 \\
\text { and } 10\end{array}$ & FLQ & $\begin{array}{l}\text { Death from } \\
\text { multiorgan } \\
\text { failure }\end{array}$ \\
\hline $\begin{array}{l}\text { Albert } \\
\text { et al (8) }\end{array}$ & 73 & $\mathrm{~F}$ & $\begin{array}{l}\text { IFMB } \\
\text { (150 mg } \\
\text { bimonthly) }\end{array}$ & 72 weeks & RA & $\begin{array}{l}\text { MTX (15 mg/ } \\
\text { week), } \\
\text { prednisone } \\
\text { (5 mg/day) }\end{array}$ & None & UL pneumonia & c & $\begin{array}{l}\text { LPAg- } \\
\text { negative, } \\
\text { BAL culture } \\
\text { positive } \\
\text { (serogroup 1) }\end{array}$ & FLQ & $\begin{array}{l}\text { Recovered, } \\
\text { resumed } \\
\text { IFMB } \\
\text { therapy } \\
\text { with no } \\
\text { sequelae }\end{array}$ \\
\hline
\end{tabular}

ALMB Adalimumab; ARDS Acute respiratory distress syndrome; BAL Bronchoalveolar lavage; BL Bilateral; CD Crohn's disease; COPD Chronic obstructive pulmonary disease; EP Erythrodermic psoriasis; ETCP Etanercept; F Female; FLQ Fluoroquinolone; HFOV High-frequency oscillation ventilation; IBD Inflammatory bowel disease; ICU Intensive care unit; IFMB Infliximab; IV Intravenous; JRA Juvenile-onset rheumatoid arthritis; LP Legionella pneumophila; LPAg L pneumophila antigen; M Male; MP 6-mercaptopurine; MTX Methotrexate; N/A Information not available; NSAID Nonsteroidal anti-inflammatory drugs; PCR Polymerase chain reaction; PD Pyoderma gangrenosum; RA Rheumatoid arthritis; TB Tuberculosis; UC Ulcerative colitis; UL Unilateral

young man with no wasting or dermatological abnormalities. The patient was tachypneic and the lung examination revealed diffuse rales on auscultation. The abdominal and lymphatic examinations were unremarkable. There was a partially healed anal fistula. The patient's initial $x$-ray demonstrated diffuse bilateral patchy and interstitial opacities (Figure 1A). He was started on piperacillin-tazobactam and vancomycin adjusted to renal clearance, azithromycin $500 \mathrm{mg}$ intravenously (IV) daily and caspofungin $50 \mathrm{mg}$ IV daily. Blood was drawn for cultures and urine legionella and pneumococcal antigens were requested. The patient rapidly became difficult to oxygenate and required high-frequency oscillation ventilation to maintain a partial pressure of oxygen of more than $60 \mathrm{mmHg}$. On day 2 of his admission, the legionella antigen test (Inverness-Binax, USA) returned a positive result for serogroup $1 \mathrm{~L}$ pneumophila. The patient recovered sufficiently to be extubated on day 9 of admission. He was treated with a 21-day course of azithromycin. He was left with residual severe kidney disease requiring hemodialysis secondary to acute tubular necrosis, but has otherwise fully recovered. 


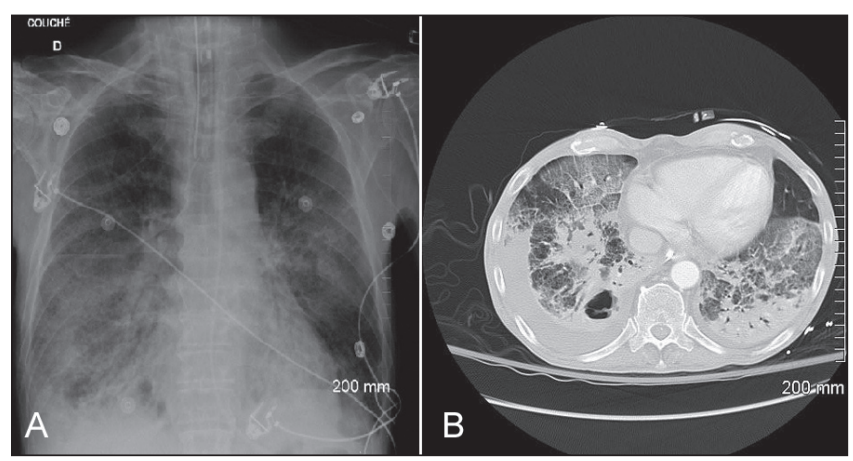

Figure 1) A The patient in case A presented in acute respiratory distress following Legionella pneumophila infection, subsequent to infliximab therapy. His initial chest $x$-ray demonstrates diffuse bilateral patchy infiltrates. B The lower cuts on a chest computed tomography scan in the infliximab-associated $\mathrm{L}$ pneumophilia infection in case B demonstrate ground-glass opacities, airspace disease and bilateral pleural effusions, right greater than left. An abscess was also found in the posterobasal segment of the right upper lobe

\section{Case B}

A 59-year-old man with a 40 pack-year history of smoking, chronic obstructive pulmonary disease, a diverting colostomy after sigmoidectomy for diverticulitis 15 years previously and Crohn's disease diagnosed in the context of small intestinal obstruction at the referring hospital five months before transfer is presented. The patient was readmitted to the referring hospital with an enterocutaneous fistula. He was treated with bowel rest, total parenteral nutrition and IV corticosteroids (methylprednisolone $20 \mathrm{mg}$ IV four times a day). The treating physician prescribed a $5 \mathrm{mg} / \mathrm{kg}$ dose of infliximab one month before transfer. The patient developed bibasilar infiltrates on his chest $\mathrm{x}$-ray, fever to $39.5^{\circ} \mathrm{C}$ and a productive cough. He was treated with piperacillin-tazobactam $3.375 \mathrm{~g}$ IV every $6 \mathrm{~h}$ and ciprofloxacin $400 \mathrm{mg}$ IV twice a day - his fever and cough subsided. A second dose of infliximab was administered the week before transfer. The pulmonary symptoms reappeared and the pulmonary infiltrates progressed to abscess formation over the next few days. On the day of transfer, the patient experienced acute respiratory failure. The inferior lung images on a computed tomography scan of his abdomen confirmed the abscess formation (Figure 1B). On arrival, the patient was awake, responsive and tachypneic, with a respiratory rate of 36 breaths/min on bilevel positive airway pressure of $12 / 5 \mathrm{cmH}_{2} \mathrm{O}$ and fraction of inhaled oxygen of $100 \%$. His blood pressure was $105 / 60 \mathrm{mmHg}$. Bibasilar rales and decreased air entry was found on pulmonary auscultation. He was tachycardic, with a heart rate of 120 beats/ min and bilateral lower extremity pitting edema. There was no indication of increased colostomy output nor was there any evident extraintestinal manifestations of Crohn's disease. His clinical condition quickly worsened, requiring urgent intubation, progressing to severe hypoxic respiratory failure and acute respiratory distress syndrome. Shortly after admission, he was referred to open lung biopsy surgery of the abscesses to identify the etiological agent. This was complicated by pneumothorax and bronchopleural fistula. He was switched to high-frequency oscillation ventilation to facilitate oxygenation and minimize barotrauma. His urine legionella antigen, sampled on admission to the ICU, was positive for serogroup 1 L pneumophila. Bronchoalveolar lavage was initially sterile, but subsequent cultures of the lung biopsy grew cytomegalovirus, and subsequent endotracheal secretion cultures grew antibiotic-sensitive Pseudomonas aeruginosa and vancomycin-resistant Enterococcus species. His ICU stay was also complicated by candidemia, attributed to his total parenteral nutrition and central venous access catheter. In the context of a known outbreak of legionellosis at the referring hospital, the etiological agent for the initial presentation was believed to be $L$ pneumophila. He was treated with a 21-day course of azithromycin $500 \mathrm{mg}$ IV daily, as well as appropriate antibiotherapy for the serial ICU-acquired pathogens. The patient's condition deteriorated as a result of a condition unrelated to legionnella. Care was withdrawn in the third week of his ICU admission, whereupon he passed away.

\section{DISCUSSION}

Legionella, a water-borne, Gram-negative bacillus, was first recognized to be a human pathogen after an outbreak of pneumonia at a 1976 American Legion convention in Philadelphia, Pennsylvania (USA). It is the etiological agent accountable for $2 \%$ to $15 \%$ of community-acquired pneumonias requiring hospitalization. Cigarette smoking, chronic lung disease, immunosuppression (including corticosteroid use) and transplant surgery are implicated as risk factors (1). Legionella preferentially invades macrophages, and in cell culture rapidly multiplies 100 - to 1000 -fold within $48 \mathrm{~h}$ to $72 \mathrm{~h}$. Its antigenic components, most notably, lipopolysaccharide, are a strong stimulus, producing TNF-alpha, which induces a cell-mediated immune response. TNF-alpha, along with interferon-gamma, interleukin-6 and interleukin-1 are believed to drive an important induction of the innate immune response and play a crucial role in combating infection (11). It stands to reason that inhibiting this response with TNF-alpha antagonists should predispose to legionellosis. In support of this hypothesis, infliximab and other TNF-alpha antagonists have been known since their inception to raise the risk of infection with other intracellular pathogens, such as Mycobacterium tuberculosis, Coccidioides immitis, Listeria monocytogenes, Histoplasma capsulatum, Aspergillus species and Pneumocystis jiroveci (3).

Epidemiological support for this argument comes from the largest case series in the literature - a French registry of patients receiving TNF-alpha antagonists (5). Data suggest a 16.5- to 21-fold higher incidence of $L$ pneumophila infection in patients treated with TNF-alpha antagonists than in the general population. This risk increase seems to hold true when compared with disease-matched patients on other immunosuppressive medication, but without exposure to anti-TNF-alpha agents.

The MEDLINE search used the terms "legion*", "Crohn*", "inflammatory bowel disease and (infliximab OR adalimumab OR etanercept)", and cross-referenced all articles retrieved for additional cases of legionellosis associated with infliximab or other TNF-alpha antagonists. There are three other documented associations of infliximab-treated Crohn's disease with $L$ pneumophila infection. One death is documented in a clinical trial (4), in which the patient died of complications of his infection 11 days after the first dose of infliximab. The second case is described in the aforementioned French registry (5). The third patient was treated in an ICU with mechanical ventilation and appropriate antibiotics, and recovered completely (2). 
Clinical cases of legionellosis associated with TNF-alpha antagonists are compiled in Table 1. Attempts were made to acquire information by contacting appropriate authors, but were unsuccessful (ie, 'N/A' in Table 1). The patients described in the literature ranged in age from 26 to 73 years (median 49 years), and affected men and women in approximately a 1:1 ratio. The case-fatality rate was $14 \%$ (three of 22 ). Two patients had successful reintroduction of the anti-TNF-alpha agent without relapse; however, another patient experienced an additional episode of legionellosis. This suggests that reintroduction of infliximab or an alternate anti-TNF-alpha agent should be considered with caution - if at all - and with careful regard to possible environmental exposure to the infective agent.

TNF-alpha antagonists are growing in popularity as treatments for a range of immune-mediated illnesses, particularly rheumatological, dermatological and inflammatory gastrointestinal diseases. These agents have been known to predispose to infection with intracellular pathogens. The present review serves to highlight the fact that TNF-alpha antagonists also predispose to infection with $L$ pneumophila, a readily diagnosable, common and highly treatable illness. Rapid recognition of legionellosis, and rapid empirical treatment with a fluoroquinolone or macrolide antibiotic significantly reduce mortality (1). Current urinary antigen tests detect only serogroup 1 , and many of the cases described were discovered on bronchoalveolar or airway secretion culture. A high index of suspicion should prompt the treating clinician to search for legionella serogroups not detected in urine testing. Therefore, physicians using anti-TNF-alpha agents to treat their patients should be aware of this association and have a low threshold for the diagnosis and treatment of legionellosis in the appropriate clinical context.

\section{REFERENCES}

1. Stout JE, Yu VL. Legionellosis. N Engl J Med 1997;337:682-7.

2. Beigel F, Jürgens M, Filik L, et al. Severe Legionella pneumophila pneumonia following infliximab therapy in a patient with Crohn's disease. Inflamm Bowel Dis 2009;15:1240-4.

3. Mancini G, Erario L, Gianfreda R, et al. Tuberculosis and Legionella pneumophila pneumonia in a patient receiving anti-tumour necrosis factor-alpha (anti-TNF-alpha) treatment. Clin Microbiol Infect 2007;13:1036-7.

4. Kohn A, Daperno M, Armuzzi A, et al. Infliximab in severe ulcerative colitis: Short-term results of different infusion regimens and long-term follow-up. Aliment Pharmacol Ther 2007;26:747-56.

5. Tubach F, Ravaud P, Salmon-Céron D, et al. Recherche Axée sur la Tolérance des Biothérapies Group. Emergence of Legionella pneumophila pneumonia in patients receiving tumor necrosis factor-alpha antagonists. Clin Infect Dis 2006;43:e95-100.

6. Li Gobbi F, Benucci M, Del Rosso A. Pneumonitis caused by Legionella pneumoniae in a patient with rheumatoid arthritis treated with anti-TNF-alpha therapy (infliximab). J Clin Rheumatol 2005;11:119-20.

7. Wondergem MJ, Voskuyl AE, van Agtmael MA. A case of legionellosis during treatment with a TNF-alpha antagonist. Scand J Infect Dis 2004;36:310-1.

8. Albert C, Vandenbos F, Brocq O, Carles D, Euller-Ziegler L. Legionellosis in patient treated with infliximab. Rev Med Intern 2004:25:167-8.

9. Eisendle K, Fritsch P. Fatal fulminant legionnaires' disease in a patient with severe erythodermic psoriasis treated with infliximab after longterm steroid therapy. Br J Dermatol 2005;152:585-6.

10. Dixon WG, Watson K, Lunt M, Hyrich KL, Silman AJ, Symmons DP; British Society for Rheumatology Biologics Register. Rates of serious infection, including site-specific and bacterial intracellular infection in rheumatoid arthritis patients receiving anti-tumor necrosis factor therapy: Results from the British Society for Rheumatology Biologics Register. Arthritis Rheum 2006;54:2368-76.

11. Friedman H, Yamamoto Y, Klein TW. Legionella pneumophila pathogenesis and immunity. Semin Pediatr Infect Dis 2002;13:273-9. 


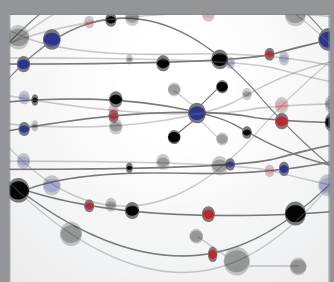

The Scientific World Journal
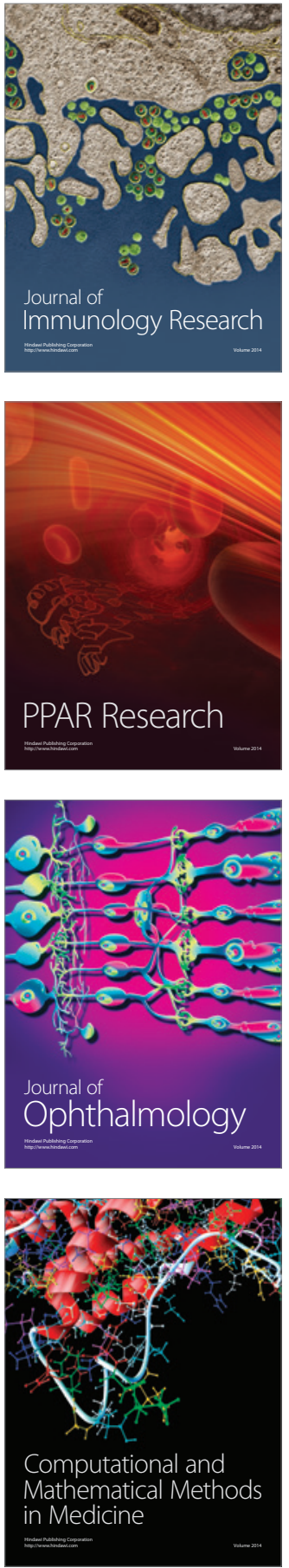

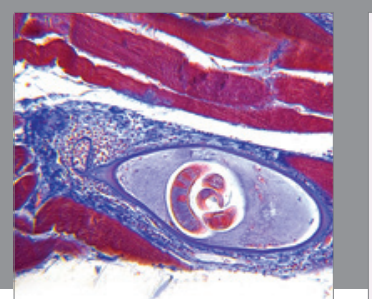

Gastroenterology Research and Practice

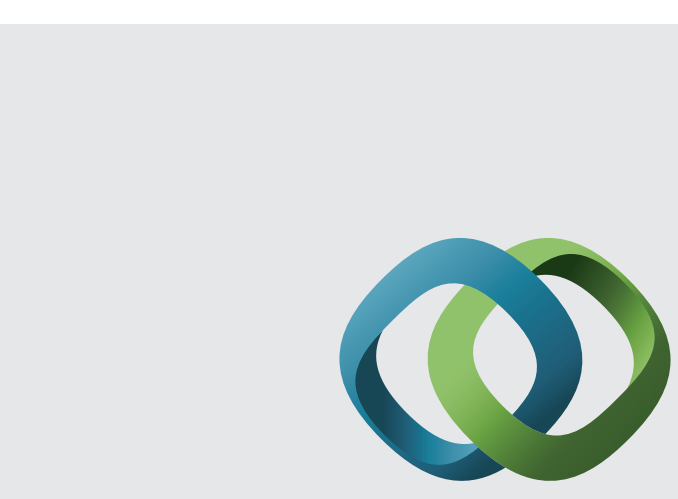

\section{Hindawi}

Submit your manuscripts at

http://www.hindawi.com
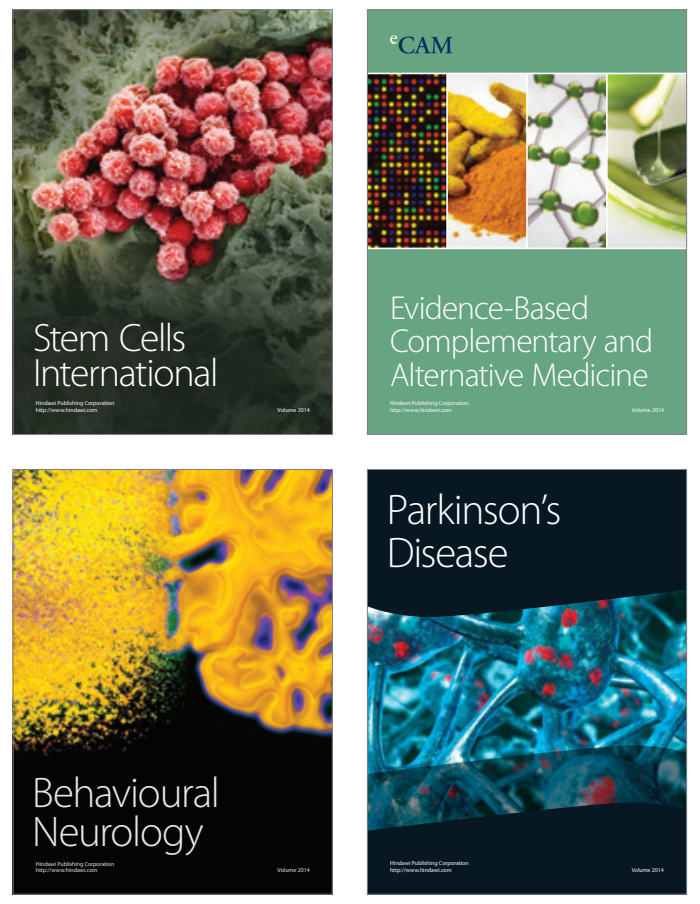
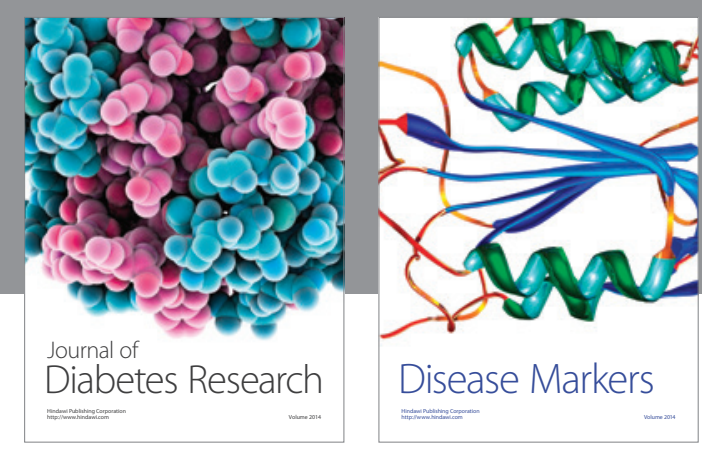

Disease Markers
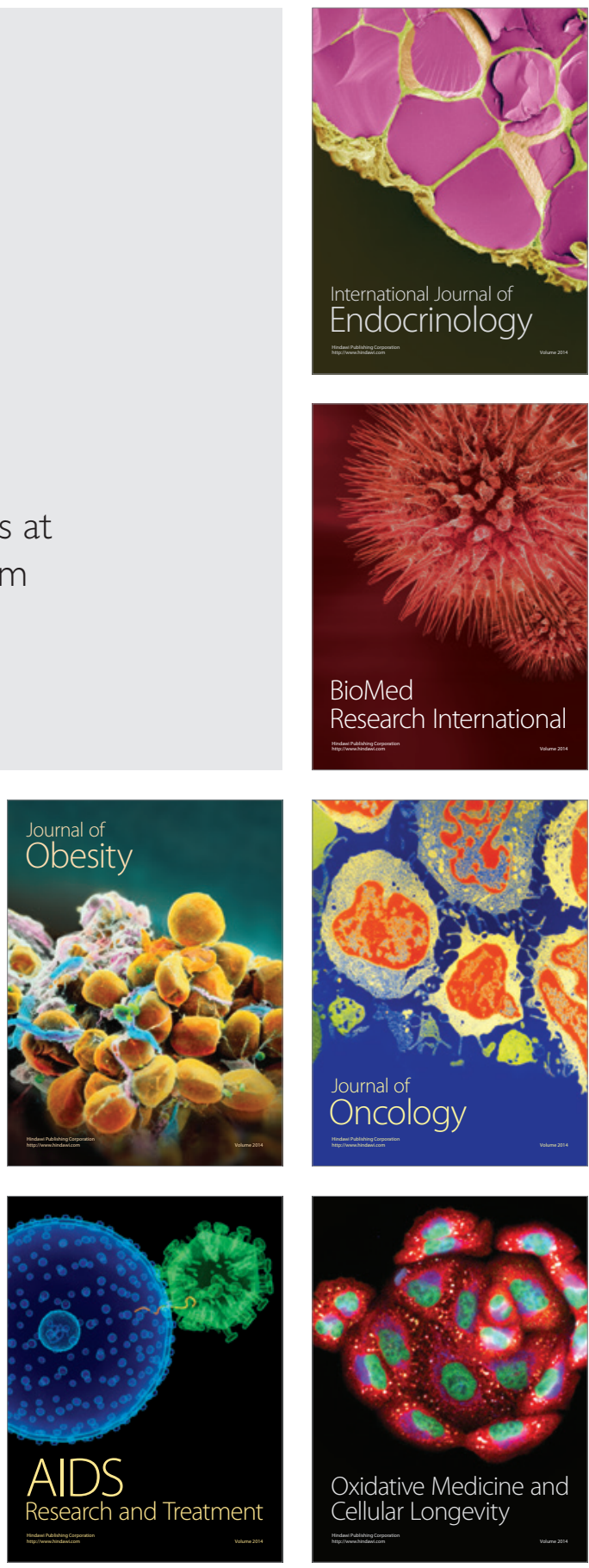